\title{
The Role of African Court on Human and Peoples' Rights Protection: The Case of Libyan Crises
}

\author{
G.K. Antigegn \\ Department of Political Science and International Studies at Bahir Dar University \\ 79, Bahir Dar, Amhara, Ethiopia
}

The emergence of regional human rights systems depicts one of the greatest achievements in the internationalization of human rights. The foundation of the charter paved the way for the birth of the court thereafter. The African Court is established by virtue of the 1998 protocol to the Charter and the court is built upon an arsenal of protective and remedial techniques. The establishment of the court has reset the stage and created a new platform for the protection of human rights in Africa. The cardinal objective of the paper is to investigate the role of African Court on human and Peoples' rights protection in Libya Crises taking the case of Saif Al Islam Gaddafi. The paper has utilized qualitative methodology. The government of Libya responded with brutal force against civilian protesters in contravention of international human rights and humanitarian law. The security force of the government of Libya killed many protesters as well. This situation intensified human rights violations and enforced many of the peoples to displace. The court issued an important ruling in March 2011, ordering provisional measures against Libya in the armed conflict in its territory. Libya government denied the claims of human rights violations in its territory and showed its willingness to subject itself to criminal investigations by the Court if necessary. The issue of the fund, independence, commitment and competence of judges to interpret mandate and jurisdiction, the willingness of the states to support and to abide by court decisions, and powers of the concerned body to enforce court decisions hampered the court from being effective. Generally, African States act in good faith with respect to the decisions of the African Human Rights Court, the court becomes more import. violations

Keywords: Human rights, African court, the protocol, Libyan crises, human rights

\section{Introduction}

The emergence of regional human rights systems depicts one of the greatest achievements in the internationalization of human rights [1]. The journey towards

(i) This work is licensed under a Creative Commons Attribution 4.0 International License https://creativecommons.org/licenses/by/4.0/ 
an effective human rights system in Africa has been long and arduous [2; 3]. The African Charter on Human and Peoples' Rights was adopted in 1981 and entered into force on 21 October 1986 [4; 2]. The adoption of the African Charter on $\mathrm{Hu}-$ man and Peoples' Rights marked a watershed in Africa's history [2]. It was believed that provisional measures by regional human rights courts assisted to provide remedies for individual applicants in particular and protect large-scale or gross violations rights of peoples in general [1].

Following the entry into force of the Charter, significant progress had registered in the human rights landscape of Africa [5]. Since the establishment of the African Charter on Human and Peoples' Rights, norms and institutions for the protection and promotion of human rights grown-up steadily. Among these developments, the establishment of an African Court on Human and Peoples' Rights stands out in particular [5]. The African Court on Human and Peoples' Rights (hereinafter- the court) was established by 1998 protocol to the Africa Charter on Human and Peoples Rights (hereinafter-the protocol) and entered in to force since $2004[6 ; 7 ; 4 ; 8]$. Since then, the court is in operation and performed different tasks on the issues of human rights.

The purpose of this piece of paper is thus to examine the role of the court in the promotion and protection of human rights with particular reference to the 2011 Libyan Crises and the case of Saif Al Islam. The paper provides something about African Court on Human and Peoples Rights, the role of this court on Libya protest and Saif Al Islam's case and assessments of the overall functions of the court respectively. The Libyan crises and Saif Al Islam's cases is intentionally chosen to demonstrate how the institution is loose and remains ineffective on the issues of African human rights politics.

\section{African court on human and peoples rights}

The African Court on Human and Peoples Rights was established by the 1998 protocol to the Africa Charter on Human and Peoples Rights [8; 9; 3]. The Court was established to complement and reinforce the protective mandate of the Africa Commission on Human and Peoples Rights by issuing binding decisions and ordering specific remedies $[6 ; 3 ; 10$. Art. 2]. The Court became operational in 2006 after its first judges were sworn in and its permanent seat is in Arusha, Tanzania $[6 ; 7 ; 4]$. The Court was ready to receive cases after it finalized its rules of procedure with the African Commission [7].

The Court was composed of eleven judges elected based on "individual capacity from among jurists of high moral character and of recognized practical, judicial or academic competence and experience in the field of Human and Peoples' Rights" [8; 10. Art. 11]. Pursuant to the protocol, judges must be nationals of members of the OAU (now AU). The protocol also provided immunity and full independence to the judges. The jurisdiction of the Court extends from the determination of disputes related to the interpretation and application of the Charter, the Protocol and other instruments ratified by state parties, to provide an advisory 
opinion to the OAU or any African organization recognized by the OAU on legal matters [6; 4;10 Art.15]. Like the other regional human rights courts, the African Court bestowed with both contentious and advisory jurisdiction.

Under Article 5(1) of the Protocol, only the Commission, States Parties and African Intergovernmental Organizations have automatic access to the Court [6; $5 ; 8 ; 10$. Art. 5]. Individuals and NGOs are only able to bring cases in their own right if the state against which they are complaining has signed a special declaration accepting the competence of the Court to hear cases $[5 ; 8 ; 9 ; 10$. Art. 5;11]. The court does not see cases unless that state ratified the protocol. Libya, in this regard, is the one among the twenty-four States who have ratified the Protocol.

\section{African Human Rights Court Response to Libyan Crises of 2011}

By the year 2011, Libya confronted with an uprising. The uprising began on 15 February in Benghazi and quickly spread to the capital city, Tripoli [12]. The revolt quickly challenged the military forces and rapidly developed into an insurgency and then into a civil war. The government of Libya responded with brutal force against civilian protesters in contravention of international human rights and humanitarian law $[1 ; 12]$. The security force of the government of Libya killed many protesters as well [12]. This situation intensified human rights violations and enforced many of the peoples to displace.

On February 24, 2011, "the Egyptian Initiative for Personal Rights, Human Rights Watch and INTERIGHTS" - submitted a joint request for provisional measures to the African Human Rights Commission against Libya [7; 1]. On February 25, 2011, the African Commission made a statement on the human rights situation, urging the government of Libya to "immediately end the violence" [7]. Nevertheless, the Libyan government continued violent repression of civilians. Subsequently, on March 1, 2011, the Commission condemned the actions of the Libyan Government [7]. Rules of Procedure of the Commission allowed that commission may refer cases of noncompliance to the African Court for enforcement via legally binding measures where that state ratified the African Court Protocol [13. Rule 118].

In this regard, Libya has ratified the protocol.

After considering the gravity of the situation, the commission brought the Libyan case before the court on March 3, 2011 [14; 15. App. 004/2011]. Article 27(2) of the Protocol allows the court to issue provisional measures in "cases of extreme gravity and urgency and when necessary to avoid irreparable harm to persons"[14; 10.Art. 27(2)]. The Court notified to the Libya government, the AU organs, state parties, and other complainants noting that the matter was of a grave and urgent. The Court issued an important ruling on March 25, 2011 ordering provisional measures against Libya [1;15. App. 004/2011]. The Court ordered Libya to refrain from any action that would result in loss of life or violation of physical in- 
tegrity of persons and to report on the steps it had taken to implement the Order "within a period of fifteen days from the date of receipt of the Order" [14].

On April 9, 2011, Libya denied the claims of human rights violations in its territory, and "expressed its willingness to subject itself to criminal investigations by the Court, if deemed necessary." [14. Note 10] Libya's response, therefore, raises questions on how the African Court should follow up such responses from states. There are no consequential provisions in relation to non- compliance by states [6]. It appears that the execution of the court's judgments really depends on the undertaking and willingness of states to cooperate. In other words, it is up to the Executive Council and/or the Assembly of the Union to adopt measures in response non- compliance.

The Protocol and the Court's procedures mandate the Executive Council to monitor the execution of decisions of the court on behalf of the Assembly [8; 10 . Art. 27]. The Executive Council or the Assembly of AU did nothing visible on the enforcement of the order against Libya. Violations of rights in Libya broadened in its kind and coverage, and NATO deployed its force for humanitarian purpose and the ongoing turmoil ended.

\section{African Human Rights Court Response to Saif Al Islam's Case}

Saif Al Islam is the second son of late Libyan leader Muammar Gaddafi. He was the only member of the Gaddafi's family left in Libya after Gaddafi and his brother Mutassim were killed on October 2011. On November 2011, Saif Al-Islam was captured and taken to Zintan and kept in detention by the Zintan-militia. Then after, it was announced that his trial will take place in Zintan, Libya [16].

The African charter allowed both individual and state communications to the African Human and Peoples' Right commission [2; 17]. With regard to this, the commission received Saif Al Islam's case in April 2012 from Ms. Mishan Hosseinioun. The case was that the 'National Transitional Council' (Government in power in Libya) detained Saif Al Islam in isolation, prohibited from contacting his family, friends, or lawyer, he has not been brought before the court and even the place where he was detained was not known [18]. After examining the case of Saif Al Islam, the commission brought it to the courts in January 31, 2013 [18]. Article 6 and 7 of the African Charter on Human and Peoples' Rights prohibits arbitrary arrest or detention, recognized presumption of innocent until proven guilty, the right to be trial within a reasonable time by an impartial court, the right to defense and have counsel of his choice [17. Note 15]. Saif Al Islam had lost all these privileges.

Article 27(2) of the 1998 protocol allowed the court to adopt provisional measures "in cases of extreme gravity and urgency" [10. Art. 27 (2)]. After recognizing the admissibility, gravity, and urgency of the case, the Court ordered the Government of Libya; to preserve the integrity of the person or detainee, refrain from taking all measures that would harm his life, allow him access to a Lawyer, allow family members and friends to visit him, and guarantee his rights to have a free and fair trial. 
Thought Saif Al-Islam's case was grave and urgent requiring an immediate response, the commission delayed to refer the case to court for issuing provisional measures. The commission received the case too early from the individual complainant and exhausted around nine months to bring it to the court for provisional order. This shows how much the commission was less responsive and less committed to discharging its mandate and less cooperative with the court in dealing with human rights protections. As stated earlier, these kinds of dalliance can be overcome when the individual and NGOs complaints get direct access to the court.

Unfortunately, as the BBC news released on 17 June, in January Saif AlIslam appeared in Suntan's court on the accusations of trading information, threatening Libya's national security and announced that the Saif al-Islam will be tried in August 2013 for charges of forming criminal gangs, inciting rape and illegal detentions [19]. On August 2013 Saif Ali Islam appeared before Tripoli court via video link from Zintan on charges of Corruption and war crimes and his trial was adjourned to May 25.

On 14 November 2013, the UN Working Group on Arbitrary Detention found that Saif Al-Islam detention in Zintan was arbitrary, and requested that the Libyan government takes steps to discontinue both the domestic proceedings against Saif Al Islam and his detention under those proceedings. The African Court of Human and Peoples' Rights has also called on Libya to ensure that he has access to a lawyer of his choice and to refrain from judicial proceedings that could cause irreparable harm to him.

Current status Generally, Saif Al Islam's case is not decided rather it is adjourned to May 25 and still there is claim by ICC to take his case into Hague by believing that Saif Al Islam could not get justice in Libya and they are trying to persuade Libya to hand him over [20]. On the other hand, Libya persist that ICC does not have jurisdiction to see cases when a State is able and willing to investigate and prosecute the same crimes and the case, does not fulfill admissibility criteria [20].

\section{Why the African Human Rights Court becomes Ineffective?}

The establishment of a strong and independent court on a regional base for the adjudications of disputes and protections of grave human rights violation is crucial in the discourses of human rights. Africans are also being aware of such facts. Though the orders passed by the African court had no immediate consequences on the situations as discussed above, the commencement of the Court by itself is a signal of great moment.

Although the system of provisional measures under the African human rights system has had its modest effect, it has been yet far from promising. As Cole [6] and Mutua [8] discussed, from the outset African leaders resisted the establishments of African court fearing that it would threaten their sovereignty. They resisted the foundation of the court placing a high emphasis on traditional conflict resolutions mechanisms and believing that third-party adjudication will create confrontations [2]. They placed a high premium on traditional African dis- 
pute settlement mechanism rather than on strict legality. Because of this and others, most of the countries abstain from ratifying the protocol and the court as the institution becomes loose.

The protocol in itself does not provide an adequate enforcement mechanism to which the decisions of the court be implemented. What makes the court significantly different from the Commission is that decisions of the court are binding on states [10]. The execution of the court's judgments requires states willingness to cooperate and undertake measures [6;10.Art.26]. As has been dealt above, the Executive Council expected to play a lot in this regard and the Constitutive Act of AU provides for sanctions in the event of non-compliance [21; 10. Art.23(2)]. But sanctions are not automatic and have to be adopted by the Assembly and hence effective enforcement of the decisions of the court entirely left in the hands of politicians [6]. Inadequate political commitment at the regional level and loose enforcement mechanisms hindered the court from being effective. As the case uncovers, enforcement mechanisms are by nature reactionary and often appeared after grave human rights violations have been committed.

Several African states are "patrimonial" implying that rule is personalized and the discretion and personality of the ruler is the source of authority $[24 ; 6]$. Reward and social relations are based on kinship and individual contractual relations rather than merit. Once authority becomes personalized, governments tend not to comply with court orders and the possibility of executing the court's decision will be a mere wish. In the absence of national commitment to liberalize and democratize politics inside, the building of genuine and effective regional systems for protecting human rights is unthinkable. Thus, domestic courts must be equipped to ensure legal, political and development infrastructures conducive for respect of human rights and should collaborate with the regional court. Integration of the Protocol into domestic law will also serve to reinforce the judgments of the court.

The protocol itself does not give a full mandate to the court rather the court was established to complement the protective mandate of the African Commission on Human and Peoples' Rights. Members to the protocol suspect that a powerful court might challenge the credibility of African political leaders in their respective countries. As a result, Heads of State were reluctant to grant the court a significant role in protecting human rights. The court had neither the authority nor the power to correct the situation. Presumably, the Court will not hear cases that do not meet the criteria. The possible overlaps and conflicts of jurisdiction between the Court and commission hindered the effectiveness of the court as well. The effective functioning of the Court threatens to be derailed by the bureaucracy [3].

As most argue, individual applicants and NGOs should be allowed to access the court. It was believed that NGOs and individuals are more sensitive to human rights violations and serve as a check on the overall conducts of governments. As the Libyan case divulged and in most of the cases violations of rights attributed to the state and states have no incentive to refer cases of human rights violations before regional tribunals. Thus, individuals and NGOs as the primary users of the 
protective functions should be automatically entitled to lodge cases before the Court. They can play an important role in the enforcement of international human rights law and restricting Individuals and NGOs to access Court affects to the effectiveness of the Court too $[5 ; 2 ; 3]$.

Judicial independence is necessary to give the Court the honor, prestige, integrity, and unrestrained liberty to do justice [2].The Independence of judges usually thwarted by fund issues seriously. Besides monetary issues, the real commitments of judges affect the effectiveness of the Court too. Commitment here implies the dedication and creativeness of judges in interpreting their mandate and jurisdiction accordingly. Courts have the potential to take the lead on many innovative trends in regional and international human rights protection.

Generally, unless African States act in good faith with respect to the decisions of the African Human Rights Court, the court becomes no more significant. They should respect the rule of law and cooperate with the human rights supervisory organs. This is the only way that the authority of the Court can be manifest and the citizens of the continent can develop confidence in the regional protection of human rights.

\section{Conclusion}

The African Human Rights Charter remains the primary normative instrument for the promotion and protection of human rights in the continent. The foundation of the charter paved the way for the birth of the court thereafter. The African Court is established by virtue of the 1998 protocol to the Charter and the court is built upon an arsenal of protective and remedial techniques. The establishment of the court has reset the stage and created a new platform for the protection of human rights in Africa. The African Court promises to strengthen the African human rights system's protective functions. The court was mandated to pass provisional measures in case of grave violations of human rights.

In this regard, the court issued an important ruling in March 2011, ordering provisional measures against Libya in the armed conflict in its territory. Libya government denied the claims of human rights violations in its territory and showed its willingness to subject itself to criminal investigations by the Court if necessary. This reply challenged the court on how to follow up with such responses from states. The orders remained without much force due to lack of political will and effective follow-up procedures from the African Union. It must be noted that unless its judgments are enforceable without state cooperation, the court will end up.

The issue of the fund, independence, commitment and competence of judges to interpret mandate and jurisdiction, the willingness of the states to support and to abide by court decisions, and powers of the concerned body to enforce court decisions hampered the court from being effective.

All in all, unless African States act in good faith with respect to the decisions of the African Human Rights Court, the court becomes no more important. 
They should respect the rule of law and cooperate with the human rights supervisory organs. This is the only way that the authority of the Court can be manifested and the citizens of the continent can develop confidence in the regional protection of human rights.

\section{REFERENCES}

[1] Juma, Dan Provisional Measures under the African Human Rights System: the African Court's order against Libya. 2012. Vol. 30, No. 2, pp. 345-373.

[2] Udombana, Nsongurua Toward the African Court on Human and Peoples' Rights: Better Late than Never. Yale Human Rights and Development L.J. 2000. Vol. 3:45. pp. 55-111.

[3] Wachira George African Court on Human and Peoples' Rights: Ten years on and still no justice. Minority Rights Group International. 2008 URL: http://www.refworld.org/p dfid/48e4763c2.(pdf). Accessed: 05.06.2019.

[4] Enonchong, Nelson The African Charter on Human and Peoples' Rights: Effective Remedies in Domestic Law? Journal of African Law, Vol. 46, No. 2, pp. 197-215.

[5] Juma, Dan Access to the African Court on Human and Peoples' Rights: A Case of the Poacher turned Gamekeeper. Essex Human Rights Review, 2007. Vol. 4 No. 2.

[6] Cole, Rowland The African Court on Human and Peoples' Rights: will political Stereotypes form an obstacle to the enforcement of its decisions? The Comparative and International Law Journal of Southern Africa. 2010. Vol. 43. No. 1, pp. 23-45.

[7] Dolidze, Anna African Court on Human and Peoples' Rights - Response to the Situation in Libya. American society of international law. 2011. Volume 15, Issue. 20.

[8] Mutua, Makau The African Human Rights Court: A Two-Legged Stool? $\mathrm{Hu}$ man Rights Quarterly. The Johns Hopkins University Press. 1999. Vol. 21, No. 2, pp. 342-363.

[9] Scats, Sonya Africa's New Human Rights Court: Whistling in the Wind?" Briefing Paper, Chatham house 2009 URL: www.chathamhouse.org.uk. Accessed: 10.06.2019

[10] Protocol to the African Charter on Human and Peoples' Rights on the Establishment of an African Court on Human and Peoples' Rights. 1998. OAU Doc. OAU/LEG/EXP/AFCHPR/PROT (III) URL: http://www1.umn.edu /human rights/Africa/courtprotocol2004.html Accessed: 05.06.2019

[11] African Court. History URL: http://african-court.org/en/index.php/about-thecourt/brief-history Accessed: 05.06.2019

[12] Lacher, Wolfram The Libyan Revolution and the Rise of Local Power Centers. Mediterranean Politics. Berlin: Maghreb, German Institute for International and Security Affairs (SWP). 2012.

[13] African Commission on Human and Peoples' Rights. Rules of the Procedure of the African Commission on Human and Peoples' Right. 2010. URL: http://www.achpr.org/files/instruments/rules-of-procedure rules of procedure 2010en pdf. Accessed: 05.06.2019.

[14] International Federation for human rights. URL: http://www.fidh.org/TheAfrican-Court-on-Human-and peoples' rights. Accessed: 06.06.2019.

[15] African Commission on Human and Peoples' Rights vs. Great Socialist People's Libyan Arab Jamahiriya Application No.004/2011. URL: http://www.africancourt.org/en/ Images/documents/ Court/Cases /case_ sum- 
maries /Application_No_004- Libya summary_august_2011_updated.pdf Accessed: 06.06.2019.

[16] Treat Gaddafi's son with dignity: African court. URL: http://www.24tanzania.com/ treat-gaddafis-son-with-dignity-african-court/. Accessed: 06.06.2019.

[17] African (Banjul) Charter on Human and Peoples' Rights. OAU Doc. CAB/LEG/67/3 rev. 5, 21I.L.M.58. 1982. URL: http://www1.umn.edu/ humanrts/instree/z1 afchar.htm. Accessed: 08.06.2019.

[18] African Court on Human and Peoples' Rights. African commission on Human and Peoples Rights v. Libya, order of provisional measures, application no.0012/2013. URL: www.africacourt.org /images/documents/ OrdersFiles/ ORDER_Application_002_2013_Africa_commission_v_libya.pdf Accessed: 05.06.2019.

[19] Saif al-Islam Gaddafi to be tried in Libya in August. URL: http://www.bbc.co.uk/news/world-africa-22945159 Accessed: 06.06.2019

[20] Libya/ICC: Saif Al Islam custody decision: ICC should do better. URL: http://www.npwj.org/ICC/LibyaICC-\%E2\%80\%9CSaif-Al-Islam-custody-decisionICC-should-do-better\%E2\%80\%9D.html Accessed: 05.06.2019.

[21] Constitutive Act of the African Union. 2002. URL: https://au.int/sites/ default/files/pages/34873-file-constitutiveact_en.pdf Accessed: 06.06.2019.

[22] Clapham, Christopher Africa and the international System: the politics of state survival. Cambridge University Press.1996.

\title{
Information about the author:
}

Antigegn Getahun Kumie - Lecturer and Researcher, Department of Political Science and International Studies at Bahir Dar University (Ethiopia) (ORCID-ID: 0000-0002-88710757) (e-mail: getkumie@yahoo.com)

Научная статья

\section{Роль африканского суда по защите прав человека и народов: случай ливийского кризиса}

\author{
Г.К. Антигегн \\ Университет Бахр-Дар \\ 79, Bahir Dar, Amhara, Ethiopia
}

Появление региональных систем защиты прав человека является одним из величайших достижений в области интернационализации прав человека. Появление Хартии о правах человека подготовило почву для последующего формирования соответствующего суда. Африканский суд учрежден на основании протокола 1998 года к Хартии, и суд построен на арсенале защитных и процессуальных методов. Создание суда стало новой вехой и основой для создания платформы для защиты прав человека в Африке. Основная цель данной работы - изучить роль Африканского суда в защите прав человека и народов в периоды Ливийских кризисов, включая рассмотрение политики Саифа Аль-Ислама Каддафи. В статье использована качественная методология. Правительство Ливии ответило жестокой силой против гражданских демонстрантов в нарушение меж- 
дународных норм в области прав человека и гуманитарного права. Силы безопасности правительства Ливии также убили многих протестующих. Эта ситуация усилила нарушения прав человека и вынудила многих людей переселиться. В марте 2011 года суд вынес важное постановление, предписывающее временные меры против Ливии в ходе вооруженного конфликта на ее территории. Правительство Ливии отрицало заявления о нарушениях прав человека на своей территории и продемонстрировало свою готовность подвергнуть себя уголовному преследованию со стороны Суда в случае необходимости. Вопросы о финансировании, независимости, обязательстве и компетенции судей для толкования мандата и юрисдикции, готовности государств выполнять и поддерживать судебные решения и действия соответствующего органа по обеспечению исполнения судебных решений препятствовали эффективности суда. В целом африканские государства действуют добросовестно в отношении решений Африканского суда по правам человека, роль данного суда становится более важной.

Ключевые слова: права человека, африканский суд, протокол, ливийские кризисы, нарушения прав человека

\section{Сведения об авторе:}

Антиген Гетахум Кумие - лектор и исследователь кафедры политологии и международных исследований Университета Бахир-Дар (Эфиопия) (ORCID-ID: 00000002-8871-0757) (e-mail: getkumie@yahoo.com) 